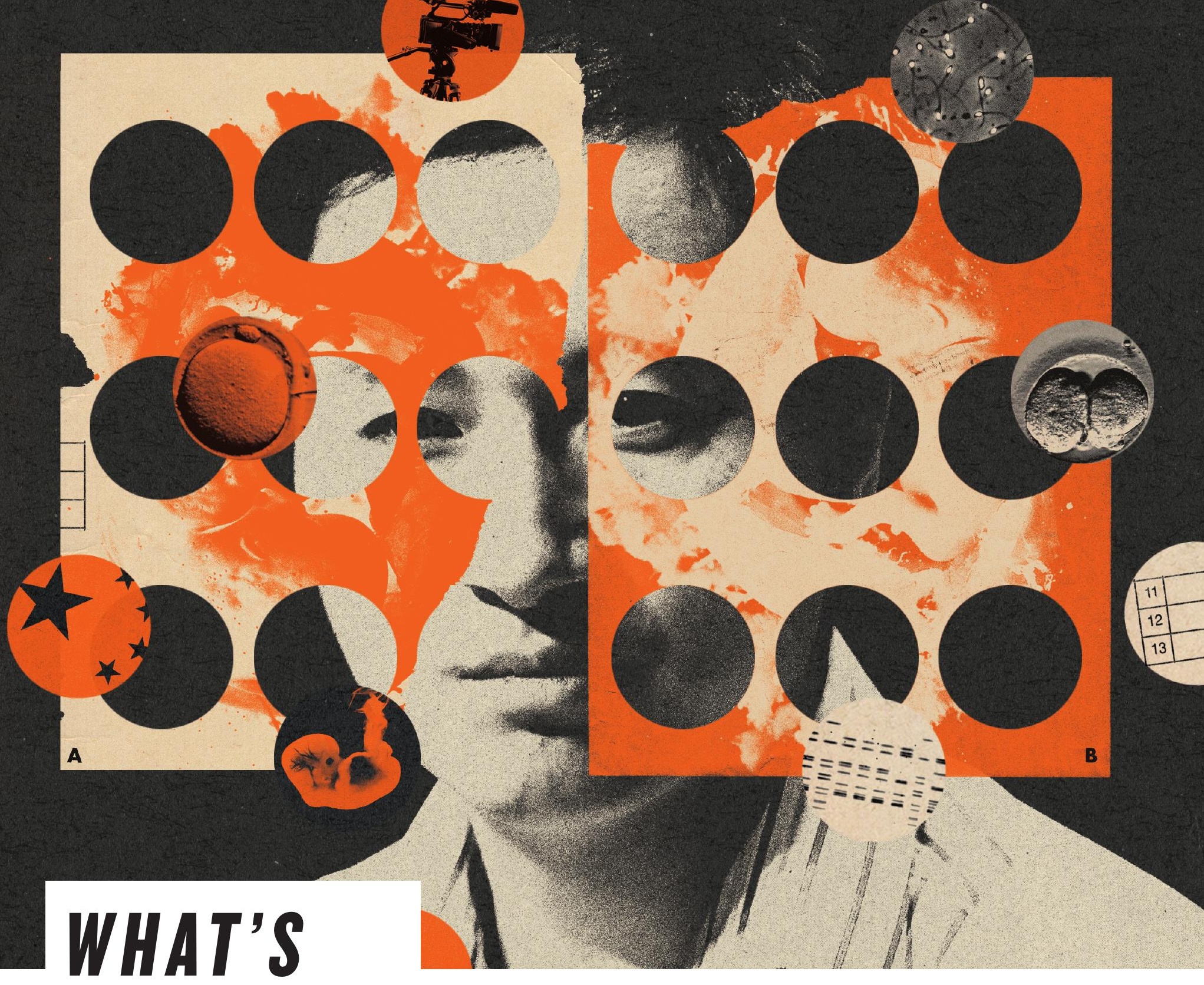

\section{NEXT FOR}

CRISPR BABIES?

Following last year's bombshell revelation, investigations mount and debates swirl about the future for gene-edited humans.

\section{Here are the four most pressing questions.}

I $\mathrm{n}$ the three months since He Jiankui announced the birth of twin girls with edited genomes, the questions facing the scientific community have grown knottier.

By engineering mutations into human embryos, which were then used to produce babies, He leapt capriciously into an era in which science could rewrite the gene pool of future generations by altering the human germ line. He also flouted established norms for safety and human protections along the way.

There is still no definitive evidence that the biophysicist actually succeeded in modifying the girls' genes - or those of a third child expected to be born later this year. But the experiments have attracted so much attention that the incident could alter research for years to come.

Chinese authorities are still investigating $\mathrm{He}$, and US universities are asking questions of some of the scientists he consulted. Meanwhile, calls for an international moratorium on related experiments, which could affect basic research, have motivated some scientists to bolster arguments in favour of genome editing.
Some are concerned about how the public scrutiny will affect the future of the field, whether or not researchers aim to alter the germ line. "The negative focus is, of course, not good," says Fredrik Lanner, a stem-cell scientist at the Karolinska University Hospital in Stockholm, who has been editing genes in human embryos to study how cells regulate themselves.

But others predict that the He affair might propel human gene editing forwards. Jonathan Kimmelman, a bioethicist specializing in human trials of gene therapies at McGill University in Montreal, Canada, argues that definitive action in the wake of the scandal could expedite global cooperation on the science and its oversight. "That would stimulate, not hinder, meaningful advance in this area," he says.

Here, Nature explores four questions still lingering around the births.

\section{WHAT WILL HAPPEN TO HE - AND THE CHILDREN?}

He has been criticized, but not just because he pursued germline editing. He also neglected to do adequate safety testing and failed to follow standard procedures in procuring participants. 
He was subsequently censured by the health ministry in Guangdong, where he worked, and fired from his university. He did not respond to Nature's multiple attempts to contact him.

At this point, further penalties seem to be in the hands of the police. There are a range of criminal charges that He could face. While recruiting participants, $\mathrm{He}$ and his team agreed to cover the costs of fertility treatment and related expenses, up to 280,000 yuan (US $\$ 42,000)$. He also stipulated that participants would have to repay costs if they dropped out. Liu Ye, a lawyer at the Shanghai Haishang Law Firm, says that if such payments are found if to count as coercive measures, they could constitute a crime. Guangdong province also found that He used forged ethics-review documents during recruitment of participants and swapped blood samples to skirt laws against allowing people with HIV to use assisted reproductive technologies.

He claims to have disabled a gene called CCR5, which encodes a protein that allows HIV to enter cells. He was aiming to mimic a mutation that exists in about $10 \%$ of Europeans, and helps to protect them from HIV infection. But He might have inadvertently caused mutations in other parts of the genome, which could have unpredictable health consequences. ( $\mathrm{He}$ claims to have found no such mutations.) Also, CCR5 is thought to help people fight off the effects of various other infections, such as West Nile virus. If the gene is disabled, the girls could be vulnerable. If they do suffer in a way that is linked to He's procedure, and $\mathrm{He}$ is found to have been practising medicine illegally, he could be sentenced to between three and ten years in prison, says Zhang Peng, a criminal-law scholar at Beijing Wuzi University. But identifying those health effects could take years.

He promised to follow up with the girls until they were 18 years old, but it is unlikely that the health ministry, which ordered He to stop doing science, will allow him to be involved in the evaluations. It is not known what, if any, special measures are being taken to look out for the girls' health or to track the other pregnancy.

\section{WHAT ABOUT THE OTHER SCIENTISTS IMPLICATED?}

Soon after He revealed his experiment, it became clear that he did not act alone or in secrecy. The responsibility of other researchers who were in the know became hotly debated.

The senior researcher with the most intimate knowledge of the work seems to be Michael Deem, a biophysicist at Rice University in Houston, Texas. Deem was once He's adviser, and is a member of the scientific advisory board of a Shenzhen-based genome-sequencing company that He founded. Deem was reportedly also a senior author on a paper - which remains unpublished - describing He's experiments, and is said to have been present during the recruitment of participants. What role he had is not clear. Deem's lawyers acknowledge that Deem sometimes comments on He's papers. But they insist that Deem does not do human research, and did not do so for this project. They say that he did not attend recruitment or informed-consent meetings, did not authorize the use of his name as an author on any human-gene-editing paper and was not a senior author on the paper. Rice University is investigating Deem's involvement.

Other scientists have been chastised for doing nothing to raise alarms about the work. He Jiankui told many US-based academics

\section{THE LEGAL LANDSCAPE}

A 2016 survey in Science examined existing laws (legislation) and documented policies (regulation) that explicitly govern gene editing or might be applied to such activities. The survey labelled countries as restrictive, permissive or something in between. But specialists disagree over whether rules in some nations might be intepreted to permit gene editing (see page 455).

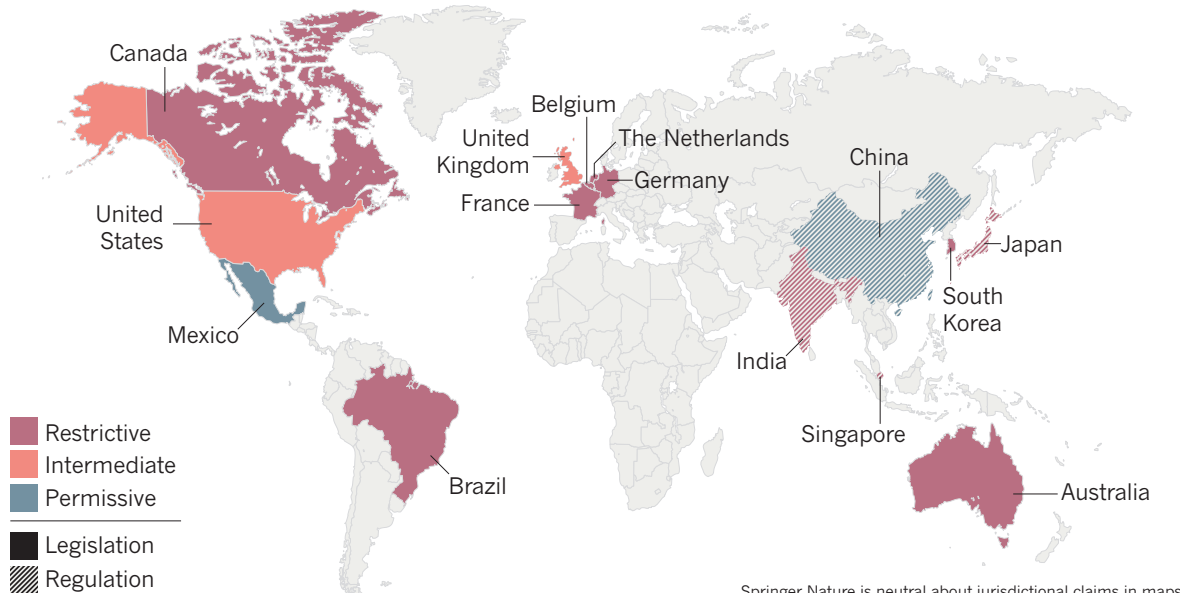

about what he was doing, including three at Stanford University in California, and Craig Mello, a Nobel-prizewinning molecular biologist at the University of Massachusetts Medical School in Worcester, who was an adviser for a company founded by He. Most of them say that they advised He against proceeding.

Mello says He ambushed him during a break at an advisory board meeting to tell him of his plans and then notified him of the pregnancies by e-mail. "I immediately expressed my concern and condemnation," says Mello.

But Natalie Kofler, a molecular biologist at Yale University in New Haven, Connecticut, argues that researchers who knew about this should have done more. The whole episode, she says, is evidence of a growing divide between the values scientists proclaim, and those they actually uphold (see page 427). Kimmelman shares those concerns, and says that by remaining silent, scientists are in danger of creating a "latency period" in which dangerous practices can emerge and evolve in a vacuum. "It often takes a debacle for people to realize that silence can often be a form of complicity," he says.

Stanford stem-cell biologist Matthew Porteus says he didn't speak up for three reasons: he thought he had dissuaded $\mathrm{He}$, he wanted to respect He's request for confidentiality and he didn't know where or how to report what he had heard. Others cite similar reasons.

Alta Charo, who specializes in law and bioethics at the University of Wisconsin-Madison, whistle. Had the research been conducted in the United States, a scientist could have contacted the Office for Human Research Protections or the Office of Research Integrity. But China has different values and opaque regulations. "If it is happening elsewhere, a scientist may be wholly unfamiliar with the norms and laws in that foreign country," says Charo. agrees that it was unclear how any of these individuals could have effectively blown the 
genetic disease and analysed genes important in early embryo development, including some implicated in the failure of some pregnancies.

The experiments triggered warnings. Although the scientists involved touted their work as careful basic research, many ethicists saw only one possible outcome: a clinical application not unlike what $\mathrm{He}$ has claimed to have done. Following the fiasco with $\mathrm{He}$, will those who are conducting embryo experiments face a backlash?

Some think that the outrage over He's acts will pass before that happens. "News cycles are just so short these days," says Kimmelman. "I'd be surprised if there are any major disruptions to research as a result of this."

But Shoukhrat Mitalipov, a reproductive biologist at the Oregon Health \& Science University in Portland, fears the controversy could affect factors such as funding and regulatory approvals. Mitalipov is working on ways to repair mutated genes in human embryos, and hopes that the approach can one day be used to edit out heritable diseases. The US government prohibits federal funding for such experiments, but Mitalipov and a handful of other US researchers have managed to find other grant money for the work. Right now, Mitalipov is cautious. "It might be a bit early to evaluate a backlash," he says. "For sure, this case did not help."

Some scientists have called for a global moratorium on all research that would tinker with the genes of human embryos, whether or not the embryos are subsequently implanted. The concern is that any such research could lead to other premature attempts. "As we have clearly learnt from China, nothing prevents someone from going rogue," says Fyodor Urnov, an Innovative Genomics Institute investigator at the University of California, Berkeley. He argues that such attempts could taint other safe and ethical uses of gene editing, such as his efforts to correct mutations in adult cells, which would not alter the germ line. "I am strongly for a complete moratorium on all embryo editing," he says.

Momentum has grown for some sort of international moratorium, and powerful figures such as Francis Collins, director of the US National Institutes of Health, have voiced support for one. Some countries, including Canada, already have policies that ban the use of human-embryo gene editing even if there is no intention of implanting the embryo (see 'The legal landscape').

The future of embryo editing, especially with the intention of producing babies, might depend on the debate over the need for it. Many sceptics point out that, although gene editing can help to avoid passing on some disorders, many of these conditions can already be avoided using a technique known as preimplantation genetic diagnosis (PGD) in which embryos created through in vitro fertilization are screened for specific mutations.

But, in the wake of the He scandal, some prominent scientists and bioethicists have gone to bat for gene editing. In three articles ${ }^{5-7}$ published earlier this year, George Daley, Robin

\section{TIMELINE HUMAN GENEEDITING}

\begin{abstract}
March 2015: Chinese researchers become the first to edit genes in a human embryo. June 2016: He Jiankui launches a project to edit genes in human embryos, with the goal of a live birth.

March 2017: He starts recruiting couples (each with an HIV-positive father) for the experiments.

Early November 2018: Gene-edited twin girls are reportedly born, and a second pregnancy with a third gene-edited embryo is established.
\end{abstract}

\section{5-26 November 2018: The MIT}

Technology Review reveals the existence of the research programme; the Associated Press quickly goes public with the story of the girls' birth.

28 November 2018: He offers details about his work at a gene-editing summit in Hong Kong and is roundly criticized. November-December 2018: China's National Health Commission orders an investigation into He's work.

January 2019: He is censured by the Guangdong health ministry and fired from his university.

\section{March 2019: A World Health}

Organization committee will meet to set guidelines for human gene editing.

August 2019: Third gene-edited baby expected.

Lovell-Badge, Julie Steffann and Charo all voiced support for it as a necessary alternative to PGD when there are too few embryos to find one suitable for implantation, and in rare cases when both parents have two copies of a disease mutation. In some instances, gene editing might be the only way to ensure fertility treatments are successful, says bioethicist Tetsuya Ishii of Hokkaido University in Sapporo, Japan.

\section{WHERE WILL THE NEXT CRISPR BABIES BE BORN?}

Although He's plans to win support for his project backfired, no one doubts that there will be more mavericks like him. The technique is easy; some of its applications are compelling; and the publicity can be enormous. But where and under what circumstances another gene-edited baby could be conceived is anyone's guess.

China would be an obvious choice, having produced the majority of gene-edited human embryos for research. The country also has an ambiguous stance towards gene editing.

But He's actions seem to have embarrassed China, judging by the removal of references to him from government websites and censorship on social-media platforms such as WeChat. (It was one of the top ten censored topics of 2018.) He's actions might prompt China to develop new regulations and better institutional oversight, says Leigh Turner, a bioethicist at the University of Minnesota in Minneapolis. In December, the education ministry called on universities to investigate whether any of their researchers were engaging in controversial gene-editing activity. And China's annual legislative meetings start on 3 March, so stricter laws could be around the corner.

But there are many places with lax policies governing new biomedical technologies. Ishii has surveyed countries with clinics that offer mitochondrial replacement therapy (MRT), a controversial procedure that has been used to correct genetic defects and boost success in pregnancies. MRT is forbidden in many countries because of uncertainties about its safety, but Ishii has identified clinics offering the procedure in Russia, Ukraine, Spain, Albania and Israel. Most of these also have lax regulations on gene editing, so the clinics could begin to offer untested services to curious parents at any time. "There are so many candidates," he says.

Kimmelman suspects the next maverick will emerge from a large country: the more scientists there are, the more chances there are for 'anomalous' behaviour. It would probably be a nation that is not well established scientifically, he says. "Incentives for a stunt like [He's] are probably diminished in a country where there are clearer and easier paths to scientific status."

Or perhaps a researcher or physician from a more developed and tightly regulated country will travel somewhere to produce a gene-edited baby. That happened with MRT, when a doctor from New York travelled to Mexico to help a couple interested in using the technology.

The investigations into $\mathrm{He}$ and others and any punishments they might face - could influence where researchers choose for their next attempts, says Turner. If He's collaborators outside China are subjected to sanctions, that might help to limit researchers based in countries with strict laws from working outside those jurisdictions. "What happens to Michael Deem - if in fact he was a meaningful participant in the germline gene-editing study - will also send a message," says Turner.

But the wide range of laws leaves the door open to further attempts. "If different jurisdictions adopt widely varying governance models for germline gene editing," says Turner, "it seems plausible that at least some scientists will pursue opportunities to conduct clinical research." -

\section{David Cyranoski reports for Nature from} Shanghai.

1. Liang, P. et al. Protein Cell 6, 363-372 (2015).

2. Tang, L. et al. Mol. Genet. Genom. 292, 525-533 (2017).

3. Ma, H. et al. Nature 548, 413-419 (2017).

4. Fogarty, N. M. E. et al. Nature 550, 67-73 (2017).

5. Daley, G. O., Lovell-Badge, R. \& Steffann, J. N. Engl. J. Med. https://doi.org/10.1056/ NEJMp1900504 (2019).

6. Charo, R. A. N. Engl. J. Med. https://doi. org/10.1056/NEJMms1817528 (2019).

7. Lovell-Badge, R. Development 146, dev175778 (2019). 


\section{CLARIFICATION}

The News Feature 'What's next for CRISPR babies' (Nature 566, 440-442; 2019) now includes a comment from Michael Deem's lawyer, in which he says that Deem was not a senior author on the human-gene-editing paper describing He's experiments. 